\title{
Resource-efficient supply chains: a research framework, literature review and research agenda
}

\author{
Aristides Matopoulos \\ School of Engineering \& Applied Science, Aston University, Birmingham, UK \\ Ana Cristina Barros \\ Manufacturing Systems Engineering Unit, INESC TEC, Porto, Portugal, and \\ F.G.A.F. (Fack) van der Vorst \\ Operations Research and Logistics Group, Wageningen University, Wageningen, The Netherlands
}

\begin{abstract}
Purpose - The study aims to define a research agenda for creating resource-efficient supply chains (RESCs) by identifying and analysing their key characteristics as well as future research opportunities.

Design/methodology/approach - We follow a systematic review method to analyse the literature and to understand RESC, taking a substantive theory approach. Our approach is grounded in a specific domain, the agri-food sector, because it is an intensive user of an extensive range of resources.

Findings - The review shows that works of literature has looked at the use of resources primarily from the environmental impact perspective. There is a need to explore whether or not and how logistics/supply chain decisions will affect the overall configuration of future food supply chains in an era of resource scarcity and depletion and what the trade-offs will be.

Research limitations/implications - The paper proposes an agenda for future research in the area of RESC. The framework proposed along with the key characteristics identified for RESC can be applied to other sectors.

Practical implications - Our research should facilitate further understanding of the implications and trade-offs of supply chain decisions taken on the use of resources by supply chain managers.

Originality/value - The paper explores the interaction between supply chains and natural resources and defines the key characteristics of RESC.
\end{abstract}

Keywords Systematic literature review, Logistics and supply chain design decisions, Natural resource-based view, Resource scarcity, Resource-efficiency, Sustainable supply chains

Paper type Conceptual paper

\section{Introduction}

Scarcity of natural resources is becoming one of the new areas of concern for our economic, industrial and political systems. Numerous industry and government reports (PwC, 2011, European Commission, 2011; SCU, 2012) have been released recently where growing concerns over the short-term availability of natural resources and the potential implications for firms are expressed. To some extent, this is surprising because economists have been talking about "the allocation of scarce resources" for decades, investigating resource prices and the mechanisms to mitigate resource scarcity (Barnett and Morse, 1963, Mennenga et al., 2012). Similarly, scientists from the knowledge fields of Environmental Science and Materials Science have been conducting research on natural

The current issue and full text archive of this journal is available on Emerald Insight at: www.emeraldinsight.com/1359-8546.htm

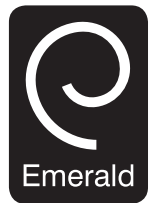

Supply Chain Management: An International Journal 20/2 (2015) 218-236

Emerald Group Publishing Limited [ISSN 1359-8546] [DOI 10.1108/SCM-03-2014-0090] resources for many decades. For example, environmental scientists developed methods and indicators to measure the use of resources and their impact on the environment (Giljum et al., 2011, 2008; Leopold, 1971), and materials scientists developed new methods for the determination, extraction and recovery of rare earth materials (Kantipuly and Westland, 1988, Binnemans et al., 2013). In Management and Business research, particularly in the field of Supply Chain Management (SCM) and despite the increased interest in sustainability, the interaction between a supply chain and natural resources usage is very often ignored. This fact is supported by natural resource-based view (NRBV) scholars (Hart and Dowell, 2011) as well as in several SCM review papers (Burgess et al., 2006, Defee et al., 2010, Ashby et al.,

(C) Aristides Matopoulos, Ana Barros, J.G.A.J. (Jack) van der Vorst. Published by Emerald Group Publishing Limited. This article is published under the Creative Commons Attribution (CC BY 3.0) licence. Anyone may reproduce, distribute, translate and create derivative works of this article (for both commercial \& non-commercial purposes), subject to full attribution to the original publication and authors. The full terms of this licence may be seen at http://creativecommons.org/licences/by/3.0/legalcode

Received 3 March 2014

Revised 26 November 2014

Accepted 11 December 2014 
2012). Resource efficiency could be arguably seen as part of the overall sustainability research agenda, but surprisingly even in recent literature reviews on sustainable SCM (Seuring and Müller, 2008; Miemczyk et al., 2012; Abbasi and Nilsson, 2012; Ashby et al., 2012; Hassini et al., 2012), very little references are made to the specific resources used, to the methods and tools applied to assess resources' usage and to the overall supply chain configuration and logistics implications of the use of specific resources. In fact, the majority of work conducted in this context either ignores the availability of natural resources as a potential supply chain risk factor (c.f. Bell et al., 2012) or, when it does not, it fails to recognise the implications and the links of resource efficiency to supply chains' overall competitive advantage. In other words, the implications of natural resource scarcity and the ability to access the various resources are not treated as a source of competitive advantage by establishing resource-efficient supply chains (RESCs), but as one of the many external operational risks that could potentially impact supply chains" "modus operandi".

The questions leading this research are the following:

RQ1. What are the key characteristics of RESCs?

$R Q 2$. What is the current state-of-the-art research on these characteristics?

$R Q 3$. What are the major research opportunities for building RESC?

To answer these questions, first, a framework with the fundamental characteristics of RESC is defined based on the existing theory and SCM literature. Next, this framework will be used to conduct a systematic review of the literature on the identified characteristics. In our analysis, we focus on the agri-food sector because it is one of the most resource-use-intensive sectors. The pressures on resources are increasing and if current trends continue in respect to the growth of the global population, the more intensive use of the world's resources will put pressure on the planet threatening the security of supply (European Commission, 2011). The industry has come under scrutiny because of various negative impacts such as resource depletion (e.g. water use for irrigation) and waste. According to DEFRA (2012), it is estimated that 2 per cent of UK business profits per year may be lost through inefficient use of resources, whereas UK businesses could save around $£ 23$ billion per year by making simple changes to use resources more efficiently and help protect the environment and natural environment. The term resources, in this paper, covers the natural renewable or depletable resources (e.g. water and oil) as well as the raw materials processed in the supply chain to produce consumer products. Subsequently, resource efficiency in supply chain terms is not just about natural resources but also highlights firm's material, energy efficiencies and the generation and impact of waste over products' full life cycles (UNEP, 2012).

The article is organised as follows: the next section presents the theoretical underpinnings leading to a proposed framework of the characteristics of RESC. Next, the methodology section provides the description of the literature review process and is followed by the results of the review and the proposed research agenda. We conclude the paper with a discussion of the findings, limitations and the conclusions.

\section{A framework for RESCs}

This section develops a framework with the fundamental characteristics and key research themes of RESCs based on existing theory and SCM literature. This framework will be the basis for the first-level coding of the systematic literature review presented further in this paper. Below, we discuss the theoretical underpinnings leading to the four characteristics of RESC: resource aware, resource sparing, resource sensitive and resource responsive. An assessment of the literature showed that two theories are leading, namely, the NRBV and resource dependence theory (RDT), which will be used to structure the findings. For each of the four RESC characteristics, we provide exemplary case examples.

\section{Natural resource-based view}

Often SCM scholars base their research on the resource-based view (RBV) (Defee et al., 2010) and competitive advantage theories (Burgess et al., 2006). RBV emphasises the role of resources (which must be valuable, rare, inimitable) and capabilities in achieving a sustained competitive advantage (Barney, 1991). Although focusing on very important company's resources, very often the interaction between an organisation and its natural environment is ignored in RBV-based research. Consequently, we base the RESC characteristics on the NRBV presented by Hart (1995) and the three key strategic capabilities identified. Key is the efficient use of natural resources and the minimisation of the impact caused by waste and emissions, which include the entire value chain or "life cycle" of the firm's product systems.

\section{Resource aware}

Resource efficiency in supply chains starts with the awareness of the use of resources and its impact. The measurement of resource use in the SCM literature has been mainly focused on (non-natural) resources such as labour, equipment, technology, transportation or energy (Chan, 2003; Gunasekaran and Kobu, 2007). The literature on green SCM has introduced environmental performance indicators, such as material and water consumption and waste and emissions production (Chien and Shih, 2007; Hervani et al., 2005). Still, creating awareness of resource usage in supply chains, by quantifying them along the supply chain, is challenging because, very often, this means measuring performance among a group of organisations. Therefore, much of the success on creating resource usage awareness depends on the companies' willingness and capability of exchanging information. Although literature shows that information sharing significantly enhances the effectiveness of supply chain practices (Zhou and Benton, 2007), companies do not always find it easy to communicate their resource usage, thus creating information asymmetry (Sarkis et al., 2011). This could be particularly the case in globally extended multi-tier supply chains where suppliers or customers may be reluctant or incapable (e.g. because of the lack of measurement and 
information systems) to share information on resource use. Although scholars in the industrial ecology field argue that if companies succeed in sharing information, they will be able to identify, trace and quantify flows of energy and materials (resource inputs and residuals), which can help not only to identify their negative impacts on natural ecosystems but also to optimise the resource efficiency of material and energy use within the supply chain (Ayers, 1989; Frosch and Gallopoulos, 1989). Therefore, to build an RESC, managers have to identify the type of (scarce) resources they use and should be aware of and develop appropriate methods and indicators to quantify them.

An example of resource awareness can be found in the automotive supply chain, which is facing a growing demand for electric and hybrid vehicles, leading to a need for two-three times more rare earths in contrast to conventional cars (e.g. 9-15 kg per car as opposed to $5 \mathrm{~kg}$ ) (Drives and Control, 2013). Ford, for example, has taken a proactive approach to understanding the issues associated with rare earth elements in their vehicles by assessing not only their usage but also where it occurs. Despite the challenges, because rare earths are used in small quantities, in a large number of components, and by suppliers far upstream in the supply chain, Ford has estimated that approximately $0.44 \mathrm{~kg}$ of rare earths are used in a typical conventional sedan (Ford, 2013). Another example taken from food industry is the "Unilever Sustainable Living Plan", which by 2020 aims to source 100 per cent of the agricultural raw materials sustainably ( 10 per cent by 2010 ; 30 per cent by 2012; 50 per cent by 2015). By taking a long-term view and working together with the non-government organisation Rainforest Alliance, Unilever hopes to ensure security of supply, reduce costs and protect scarce resources (Unilever, 2012).

\section{Resource sparing}

The NRBV states that the access and efficient management of natural resources may be a source of competitive advantage for companies; hence, RESCs have to be resource sparing to sustain this competitive advantage. This could be achieved by continuously improving operations and reducing the use of resources along its various stages, i.e. adapting product designs and production processes and creating closed-loop supply chains with regard to the way resources are recollected and re-used. This principle can be applied both in traditional forward processes, as well as in returns management, re-manufacturing, reverse logistics, product recovery and reuse.

A recent example of resource sparing is Honda's initiative to establish a new process to reuse rare earth metals extracted from nickel-metal hydride batteries for new nickel-metal hydride batteries so as to recycle precious resources. The Japanese car manufacturer is planning to apply the same process for used nickel-metal hydride batteries, also collected by Honda dealers through battery replacement, as well as used parts which is one step further towards a more closed-loop car supply chain (Honda, 2013). Back to the food industry example, Unilever was able to source 36 per cent of their agricultural raw materials sustainably by the end of 2012 . They concentrated on the top ten agricultural raw material groups, which account for around two-thirds of the volumes: palm oil, paper and board, soy, sugar, tea, fruit and vegetables, sunflower oil, rapeseed oil, dairy ingredients and cocoa (Unilever, 2012).

\section{Resource dependence theory}

RDT presents the view that organisations depend on their environment for success and survival, and therefore, they must react to changes in the supply of resources (Pfeffer and Salancik, 1978). In a supply chain context, RDT suggests that member firms are interdependent and should collaborate to combine their resource sets towards achieving higher performance gains (Paulraj and Chen, 2007; Sarkis et al., 2011). Ellram et al. (2013) warn that in the current climate of increased offshoring and outsourcing, the breadth and depth of the organisation's dependency grows, often with negative and unanticipated consequences. Because of the globally expanded supply chains, there is increased complexity, and as complexity increases, firms find it difficult to consider the entire spectrum of implications that resource changes may have. This fact led SCM scholars to identify the various supply chain risk types and their sources (Narasimhan and Talluri, 2009). Therefore, RESC should be sensitive to resource changes and responsive to them.

\section{Resource sensitive}

RESC should be capable of capturing any changes in the availability of natural resources and raw materials. A resource sensitive supply chain would be vigilant to spot any changes (with the help of suppliers and customers) in the environment that are likely to affect its potential access to resources. It is sensitive both to price variations and changes in the supply of the resources it needs because of degradation, depletion or natural disasters, as well as to global macro-trends (e.g. changes in demand patterns, population growth, geopolitical activity). Resource sensitivity is concerned with the external macro-environment issues of the supply chain, whereas resource awareness is focused on the intra-supply chain operational issues.

For example, risks over depletion of phosphate rock's global reserves (phosphorous together with nitrogen are the most critical elements - also not substitutable - for plants' growth and development) has recently led the Australian's national science agency, Commonwealth Scientific and Industrial Research Organisation to order a report on the implications of global phosphorus scarcity in Australian food supply chain (ISF, 2010). Similarly, China's increasing rare earths export restraints and quotas in the beginning of this decade created growing concerns for the US defence industry and resulted in the US congress ordering the Secretary of Defence to do an assessment of the supply and demand for rare earth materials in defence applications. The assessment would identify whether any rare earth materials would be critical to the production, sustainment or operation of significant USA military equipment; or subject to interruption of supply, based on actions or events outside the control of the US Government (Grasso, 2011). In addition, food industry is looking for robust supply chains that can deal with disturbances as a result of supplier failures due to natural disasters, shortages due to harvest failures or product recalls due to food scandals (think about the recent horse meat scandal that significantly impacted meat consumption and availability). 
This holds especially for those chains with specific characteristics that increase its vulnerability, such as seasonality in supply and demand and a limited shelf-life of products (Vlajic et al., 2012).

\section{Resource responsive}

The resource responsive characteristic of RESC follows naturally the resource sensitive characteristic because it will act upon the changes captured. The foundations of the fourth characteristic are drawn from RTD as well as from complexity and contingency theory. According to complexity theory (Brown and Eisenhardt, 1997; Anderson, 1999) organisations, and hence supply chains, are complex adaptive systems, and as such, they respond to their environment, creating dynamic, emergent realities (Choi et al. 2001). In a similar vein, contingency theory (Lawrence and Lorsch, 1967; Donaldson, 2001) suggests that there is no single, optimal course of actions, and responses will be dependent on the situation of a firm. As Walker and Jones (2012, p. 16) suggest "there is no one right way to approach sustainable SCM, and that the best course of action is contingent upon the internal and external situation". The idea that supply chains have to be responsive to external changes has already been discussed in the SCM literature. Indeed, supply chains have to be responsive to the uncertainty associated with innovative products (Fisher, 1997) and with changes in volume, mix and delivery (Reichhart and Holweg, 2007). The goal of responsive supply chains is ultimately to react quickly and cost-effectively to changing market environments (Gunasekaran et al., 2008). In the case of RESC, supply chains will have to develop strategies aimed at mitigating the effects of natural resource scarcity (Bell et al., 2012 and 2013).

In 2011, for example, Siemens AG announced the intention to establish a joint venture company for the production of neodymium-based rare earths magnets (to be used for energy-efficient drive applications and wind-turbine generators) with the Australian rare earths mining company Lynas to secure a long-term and sustainable end-to-end supply chain, from mine to magnet, to end application (Lynas, 2012). Another trend in response to increased demand for phosphate rock is vertical integration with the mining industry becoming more closely integrated with the industries that process phosphate rock and produce fertilizer. It is estimated that 70 per cent of phosphate rock producers are already integrated firms with the processing of the rock and the manufacturing of fertilizer or other phosphate products now happening within the same company (HCSS, 2012; Phosagro, 2011).

The key characteristics of RESC along with the important research themes identified are summarised in Table I. The resource aware and sparing characteristics, based mainly on the NRBV theory, are internally focused and evaluate and respond to the resource usage along the supply chain. In contrast, the resource sensitive and responsive characteristics, based mainly on the RDT, are externally focused and evaluate and respond to external resource constraints. The combination of the four characteristics will enable supply chains to create resource-specific competitive advantages and proactively react to external resource changes for sustaining the supply chain activity in the long-term. Based upon the RESC characteristics, we derived five themes central in the literature analysis. First, to create RESC, one has to identify what resources are to be taken into consideration, and therefore, we analysed the type of resources that were considered in the sample papers. Second, to understand the scope of RESC, we learned from the literature review which supply chain stages have been considered. The third and fourth themes are instrumental to create resource awareness and sensitivity because to analyse and diagnose the supply chain there is a need to understand which specific methods can be applied to assess resource usage and what environmental impact indicators may be considered. Finally, to understand what actions may be taken for RESC to be resource sparing and responsive, we analysed the Logistics and Supply Chain Management (L\&SCM) decisions considered in the sample papers.

\section{Review methodology}

The review of the literature follows a systematic review method, which aims at creating a research synthesis of the cumulative knowledge in a specific field by adopting a replicable, scientific and transparent research process (Tranfield et al., 2003; Rousseau et al., 2008). To identify research opportunities for RESC, we take a substantive theory approach, grounded in a specific domain (Glaser and Strauss, 1967; Skilton, 2011), using the agri-food sector as our means to understand RESC. This is because the agri-food industry is an intensive user of (an extensive range of) resources because of its high dependence on, for example, water (e.g. as raw material, to clean machinery or to grow crops), energy (e.g. energy consumption at the

Table I Key characteristics and themes of the resource-efficient supply chain

\section{Key characteristics and}

themes

Internal RESC characteristics

External RESC characteristics

Themes
Analyse and diagnose

Resource aware: create insights about the use of resources in the supply chain and the impact it has on performance and the environment

Resource sensitive: capture external changes in the availability of natural resources

Type of resources considered

Food supply chain stage studied

Methods applied to assess resource usage and its impact

Impact indicators of the resource usage
Act and improve

Resource sparing: continuously improve operations and reduce the use of resources along the supply chain stages

Resource responsive: develop strategies aimed at mitigating the effects of natural resource scarcity L\&SCM decisions 
farms, processing stages and distribution facilities), fertilizers (made from petroleum, minerals or from rare earth materials), pesticides (made from petroleum and chemicals), farm machinery, food processing equipment, storage, packaging and transportation/distribution means (e.g. fossil fuels used for transport in different supply chain stages). The sector accounts for around 30 per cent of the world's total energy consumption and for around 22 per cent of total green house gas (GHG) emissions (FAO, 2011). In addition, estimates indicate to 90 million tonnes of food wasted annually at European Union level, representing 179 kilos (kg) per capita (FoodDrinkEurope, 2012). Similarly, from a supply chain perspective, the sector is very challenging because it is characterised by increased imports and exports and global transport and sourcing of products because of its seasonality, perishability and production's cycle (WTO, 2009; Wognum et al., 2011). In that respect, the agri-food sector serves as an adequate context to understand the key characteristics of RESC, as well as to explore the research challenges for building RESC.

\section{Selection of articles for review}

To identify the journal articles for review, a structured keyword search was conducted on major databases and publisher websites (EBSCO, Scopus, Google Scholar, Springerlink, Wiley Interscience, Elsevier ScienceDirect, Emerald Insight, Taylor\&Francis). The aim of the review was to capture the research addressing resource efficiency that was carried out in the field of food L\&SCM. Therefore, the following keyword structure was used: "supply chain" OR "logistics" AND "sustainable" OR "sustainability" AND "environment(al)" OR "green" AND "resource efficiency" OR "resource use" OR "use of resources" AND "food" OR "agri". The search included all papers published till the end of 2012. The results were initially filtered so as to include only articles written in English that were also published in peer-reviewed journals. Next, articles were screened in detail, and all papers that were not related to agri-food (e.g. articles on bio-energy/bio-fuels, primary agricultural/animal production) were excluded. Similarly, articles related to the social/ethical aspects of sustainability as well as articles dealing with perceptions of sustainability (e.g. consumer or employee surveys) were also excluded. Ultimately, 96 articles published between 1998 (when the first relevant article appeared) and 2012 were included in this review.

\section{Review process and coding rationale}

The data analysis was divided into a two-stage coding process (Seuring and Müller, 2008) and made use of NVivo software to systematically assess the papers (c.f. Beekhuyzen, 2007). Initially, a first-level coding with five key themes was defined based on the RESC characteristics presented above (Table I). The papers included in the review were then assessed in NVivo according to this first-level coding. The second-level coding emerged then inductively from the analysis of the sample papers in NVivo. Table VII at the end of the results section presents the final coding structure. The use of the RESC framework of key characteristics and the coding scheme helped to increase validity of the review (Krippendorff, 2004).
To assure reliability of the review process, the NVivo file was shared among the involved researchers to allow the verification of classifications. Differences in judgements were analysed in periodic meetings.

Descriptive analysis of the papers selected for review As stated, 96 articles were analysed. Figure 1 shows the distribution of the papers included in the review per year of publication. Starting in 2008, a growing interest in the field is observed because there are five times more articles published in 2012 compared to 2008 .

The articles considered for review appeared in 47 different journals covering a large spectrum of disciplines. Although the analysis shows that approximately 40 per cent of the articles were published in three journals: Fournal of Cleaner Production (22), Food Policy (10) and the International fournal of Life Cycle Assessment (7). The rest of the papers are distributed across a range of other journals which can be found in Table II. The diversity and number of journals that publish articles dealing with resource efficiency in agri-food supply chains show the wide scope of the topic and the numerous disciplines involved. However, because various publication outlets specific to this domain exist, it is understandable that not so many papers in L\&SCM journals appeared in the review.

Based on Seuring and Muller's (2008) work, articles were classified into one of the following five research methods: quantitative modelling, theoretical or conceptual, case study, survey or literature review and an overview of the various types of research methods is presented in Table III.

\section{Results}

This section provides the results of the review organised by the key themes considered (Table I) to understand how resource efficiency has been addressed so far in the literature.

\section{Type of resources considered}

In total, there are 52 articles on the use of resources (see also Table VI for an overview), of which, 15 have specifically addressed the use of energy (Khan and Hanjra, 2009, Mundler and Rumpus, 2012, Vanek and Sun, 2008, Davis and Sonesson, 2008, Dalgaard et al., 2011). Water use was found to be the core topic in eight articles (Jeswani and

Figure 1 Distribution of the articles included in the review over time

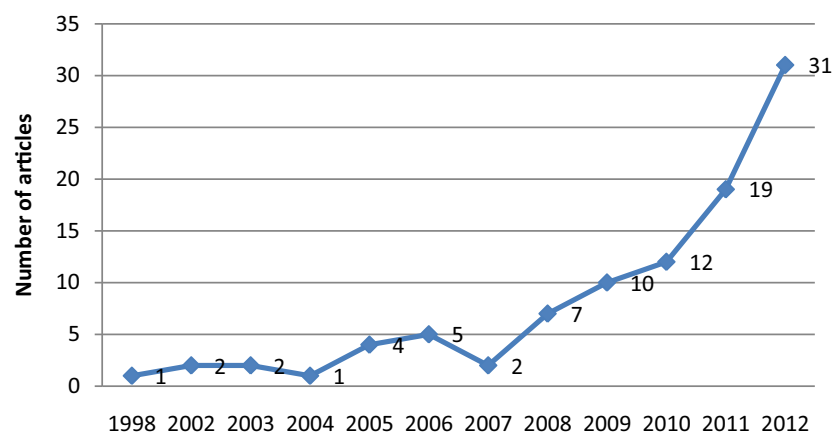

Year of publication 
Table II Journal outlets of reviewed papers

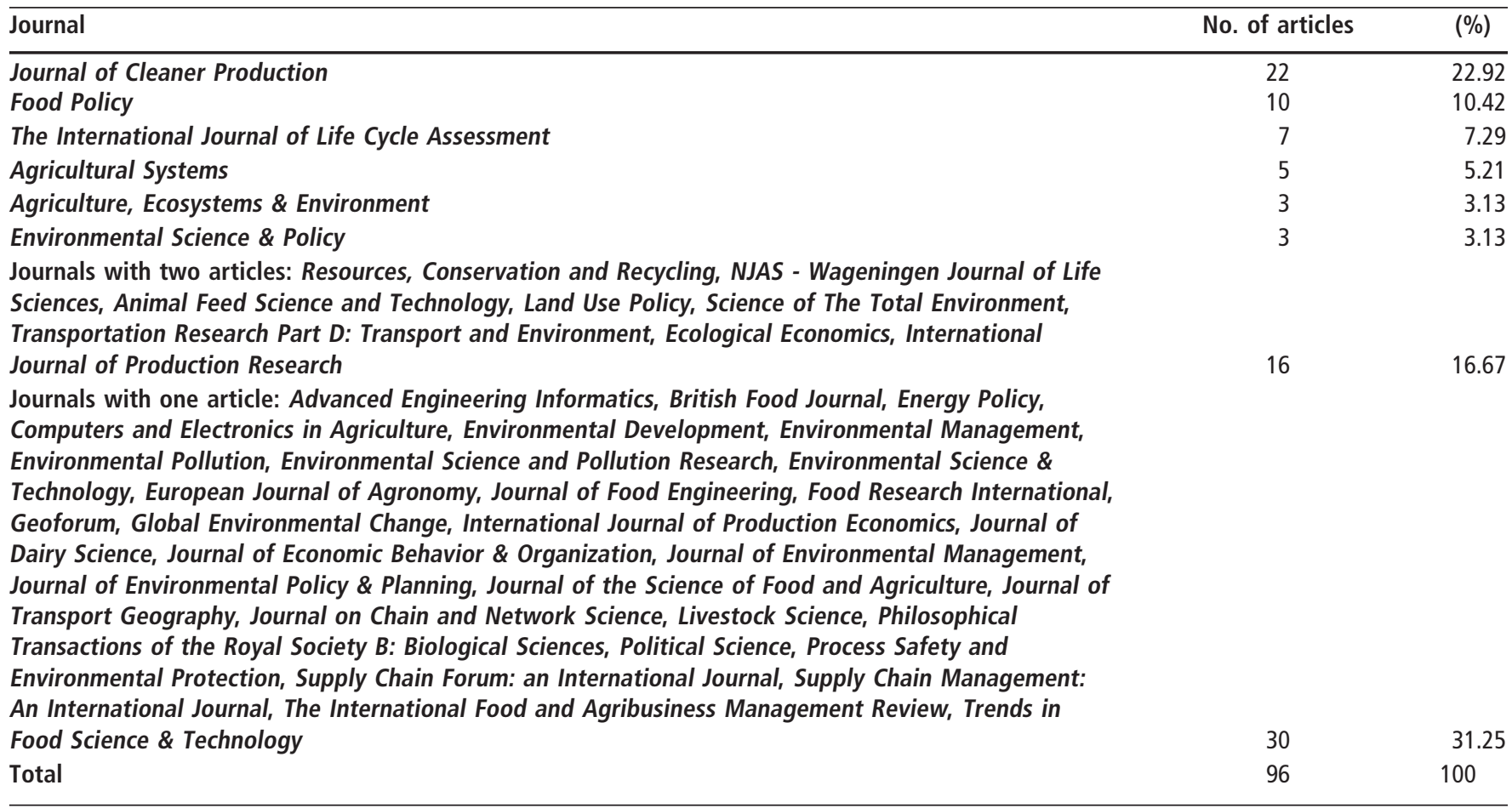

Table III Research methodologies used in the sample of papers

\begin{tabular}{lcc}
\hline Research methods & $\begin{array}{c}\text { No. of matching } \\
\text { sources }\end{array}$ & $\mathbf{( \% )}$ \\
\hline Case study & 42 & 43.75 \\
Quantitative modelling & 23 & 23.96 \\
Theoretical and conceptual & 15 & 15.63 \\
Literature review & 10 & 10.42 \\
Survey & 6 & 6.25 \\
Total & 96 & 100.00 \\
\hline
\end{tabular}

Azapagic, 2011, Milà i Canals et al., 2010, Herath et al., 2012, Page et al., 2012, Ridoutt et al., 2010, Ridoutt and Pfister, 2010, Zonderland-Thomassen and Ledgard, 2012, Kist et al., 2009). In addition, seven articles emphasised the use of land (Ponsioen and Blonk, 2012, Mattila et al., 2012, Nijdam et al., 2012, Plassmann et al., 2010).

Packaging waste and use of fertilizers has not received much attention so far. For example, regarding fertilizers' use, only two articles were found to investigate this (Dawson and Hilton, 2011, Kummu et al., 2012), and similarly, packaging waste was covered in only two articles (Henningsson et al., 2004, Schliephake et al., 2009). The use of abiotic and/or biotic material, water and/or energy was also analysed for the lifecycle phases' raw material procurement, production, use and waste treatment by Gerbens-Leenes et al. (2003), Liedtke et al. (2010). A closer look of these papers reveals that researchers have primarily investigated the use of resources from the environmental impact perspective, not taking into account resource scarcity risks and associated implications at the company level.
Food supply chain stage studied

Resource sparing aims at reducing resource usage in more and more closed-loop supply chains. As a consequence, it is important to discuss the boundaries of the system under consideration. Five system boundaries across the food chain were considered in the analysis (Gustavsson et al., 2011): Primary production (e.g. resources used to produce agricultural products), post-harvest handling and storage (this phase covers the use of resources from the farm till processing - e.g. product transport, freezing facilities), processing (this stage refers to the actual use of resources in processing and transforming agricultural raw materials into food products), distribution (this phase covers the use of resources required for the product to reach the consumer including wholesalers, retailers and the potential losses and waste) and, finally, consumption (refers to the use of resources at the consumers level including losses because of reaching the expiry date or quality decay). In Table IV, the total number of articles tackling each one of the five food supply chain stages is presented along with the different research methodologies used. Some articles were classified into more than one of the five food supply chain stages recognised in the literature because a number of them were found to focus on more than one stage.

Results indicate that the main emphasis is on primary production (33 articles) and the distribution stage (27 articles). Less emphasis has been placed on the processing stage (22 articles), and much less articles have included the post-harvest handling and storage phase (16 articles). As Table IV demonstrates, there is clearly an imbalance between the different research methods used, and it can be said that irrespectively of the food supply chains stage, there is a strong dominance of case study and quantitative modelling research. What is more, it 
Table IV List of articles per stage and method

\begin{tabular}{|c|c|c|c|c|c|c|}
\hline Stage Method & Case study & Literature review & Quantitative modelling & Survey & Theoretical and conceptual & Total \\
\hline $\begin{array}{l}\text { Primary production } \\
\text { Post-harvest handling and }\end{array}$ & 16 & 3 & 6 & 4 & 4 & 33 \\
\hline storage & 10 & 0 & 3 & 0 & 3 & 16 \\
\hline Processing & 14 & 0 & 4 & 0 & 4 & 22 \\
\hline Distribution & 17 & 0 & 6 & 1 & 3 & 27 \\
\hline Consumption & 5 & 0 & 2 & 0 & 2 & 9 \\
\hline Full chain & 1 & 0 & 0 & 0 & 0 & 1 \\
\hline
\end{tabular}

seems that research (with the exemption of Mintcheva, 2005) has not taken a truly broad view of the supply chain.

\section{Methods applied to assess resource usage and its impact}

The wider implementation of resource-efficient practices in the food industry is often limited by the lack of consistent and transparent data on the environmental impacts of the resource use in the food chain, earlier mentioned as part of resource awareness. As a result, there is a need to understand which specific methods, techniques and/or tools could be used to measure the resources usage and its impacts. The following methods have been identified during the review study: life cycle assessment (LCA), economic input-output (EIO)-LCA, hybrid-LCA, exergy analysis, material and energy flow analysis (MEFA), material input per service unit (MIPS), means/end analysis (MEA) and hotspot analysis. Table V presents the overview of the methods used to assess resource usage and its impact.

Concerning the methods used to evaluate the various impacts, the analysis clearly shows that LCA is by far the dominant approach (49 articles). Variations of LCA, such as EIO-LCA, have only been used in two papers (Virtanen et al., 2011, Meisterling et al., 2009). Other methods proposed include MIPS for assessing the environmental sustainability of food production and consumption of various foodstuffs (wheat-, rice- and orange-based products); however, calculations were based on the use of existing LCA and literature data and not on primary data (Mancini et al., 2012). Hotspot analysis which was applied in the coffee and the cream cheese sector is primarily used as a screening tool. The method focuses on the demand of reliable sustainability-oriented decision-making processes in complex value chains identifying high-priority areas ("hot spots") for effective measures in companies (Liedtke et al., 2010). For the remaining methods, MEFA (Sanyé et al., 2012), MEA (Jones, 2002), hybrid-LCA (Cellura et al., 2012) and exergy analysis (Apaiah et al., 2006), all methods come with unique strengths and characteristics. Overall, we observe that there is a lack of empirical and comparative research that could further support the decision to use one method over another. For example, LCA usually allows for an assessment of large systems, taking advantage of specific software and databases developed for some of the resources (e.g. water). However, the method has mainly focused on resource abstraction in industrial processes, making its use in other sectors less relevant. What is more, the reliance of LCA on already

Table V Methods to assess resource usage and its impact.

\begin{tabular}{|c|c|c|}
\hline Method & Description & \# articles \\
\hline$\overline{L C A}$ & $\begin{array}{l}\text { LCA is an ISO standardised technique to assess environmental impacts associated with all the stages of a product's } \\
\text { life from raw material acquisition through production, use and disposal (ISO 14040, 2006a, 2006b) }\end{array}$ & 49 \\
\hline EIO-LCA & $\begin{array}{l}\text { EIO-LCA method estimates the materials and energy resources required for, and the environmental emissions } \\
\text { resulting from, activities in the economy, combining LCA and economic input-output (using information about } \\
\text { industry transactions, purchases of materials by one industry from other industries and the information about direct } \\
\text { environmental emissions of industries) (Hendrickson et al., 2006) }\end{array}$ & 2 \\
\hline Hybrid-LCA & Hybrid-LCA combines process-level data with sector-level input-output analysis (Suh et al., 2004) & 1 \\
\hline Exergy analysis & $\begin{array}{l}\text { Exergy analysis is an assessment technique for systems and processes that is based on the second law of } \\
\text { thermodynamics and assesses types, causes and locations of energy losses (Marc, 2008) }\end{array}$ & 1 \\
\hline MEFA & $\begin{array}{l}\text { MEFA is an integrated, consistent accounting framework that takes into account material flow accounting, energy } \\
\text { flow accounting and the human appropriation of net primary production (Haberl et al., 2004) }\end{array}$ & 1 \\
\hline MIPS & $\begin{array}{l}\text { MIPS drawing from material flow analysis estimates the overall environmental pressure caused by products or } \\
\text { services by indicating the lifecycle-wide consumption of natural resources in relation to the benefit provided } \\
\text { (Ritthoff et al., 2002) }\end{array}$ & 1 \\
\hline MEA & $\begin{array}{l}\text { "MEA is based on a life-cycle perspective but does not follow the LCA procedures that have been developed by the } \\
\text { Society of Environmental Toxicology and Chemistry and are outlined in the ISO } 14040 \text { life-cycle assessment } \\
\text { standards" (Jones, 2002) }\end{array}$ & 1 \\
\hline Hot-spot analysis & $\begin{array}{l}\text { Hot-spot analysis "explores the most relevant factors or phases influencing, e.g. the indicator resource use in the } \\
\text { life cycle or product chain with regard to sustainability according to available literature, expert consultations or } \\
\text { stakeholder statements" (Liedtke et al., 2010, p. 1141) }\end{array}$ & 1 \\
\hline
\end{tabular}


developed databases does not take into account local or sectorial differences in terms of resources used and for supply chains which are globally expanded.

\section{Impact assessment and indicators of resource usage} Another element of resource awareness is related to the availability of relevant impact indicators to measure resource use. Impact indicators refer to the actual metrics used to measure the environmental impact of the use of resources. Our analysis indicates a strong dominance of research using GHG emissions as impact indicator of resource usage (26 papers - predominantly on carbon dioxide $\left[\mathrm{CO}_{2}\right]$ emissions and much less on methane $\left[\mathrm{CH}_{4}\right]$ or nitrous oxide $\left.\left[\mathrm{N}_{2} \mathrm{O}\right]\right)$. The second more often used indicator is the calculation of the carbon footprint (16 articles), followed by water footprint (eight articles), whereas ecological and nitrogen footprints (Leach et al., 2012) are addressed in a limited number of articles (only one for each). Also, 18 papers have looked specifically at the suitability of the methods and indicators used and proposed in the literature (Gerbens-Leenes et al., 2003; Van Passel, 2013; Plassmann et al., 2010). From these papers, we can conclude that there is a lack of complete, integrated and chain-wide indicators (e.g. decoupling indicators, basket of products indicators, waste management indicators). Furthermore, there is a lack of data that allows for the examination of the goodness of fit of the indicators, bearing in mind some of the inefficiencies discussed in the previous section of the assessment methods used.

\section{L\&SCM decisions considered}

Building RESC means adopting management practices that enable the supply chain to sense the changes in the availability of natural resources and raw materials and to adapt its structures to quickly respond to these changes. Furthermore, communication and information systems need to be implemented to create awareness of the resources and raw materials use along the supply chains, and continuous improvement and re-design of operational processes to spare resources and, consequently, the environment. This implies that to achieve RESC, several L\&SCM decisions need to take these requirements specifically into account.

The content analysis resulted in 23 papers that addressed to some degree the impacts and/or trade-offs of L\&SCM decisions in the use of resources and raw materials. Using the categorisation of decisions in standard operations and SCM literature (Cigolini et al., 2004; Hayes et al., 2005; Lambert and Cooper, 2000; Riopel et al., 2005), we divided the L\&SCM decisions needed to achieve RESC into configuration (design) and tactical/operational decisions. Table VI presents the categorisation and the references of the reviewed papers that consider each decision.

In practice, prior to making these decisions, a supply chain (resource-efficient) strategy has to be developed and agreed upon among chain partners (c.f. Hagelaar and van der Vorst, 2001). This strategy will define the sustainability objectives and associated performance indicators (Matopoulos and Bourlakis, 2010). Much has been written on the selection and shortcomings of current sustainability performance indicators (Hassini et al., 2012), but this is not the focus of this paper.

Table VI Key L\&SCM decisions needed to achieve RESC

Key decisions $\quad$ Reviewed papers

\section{Configuration decisions}

Supply chain network structure and design

\section{Product design}

\section{Communication and information network design}

\section{Tactical/operational decisions Production processes improvement}

Inventory management
strategy
Transportation network
optimisation

Supply chain coordination
Who are the supply chain members and which physical facilities will be part of the supply chain network to minimise the use of resources and raw materials?

What changes are needed in the product and packaging design to minimise the use of resources and raw materials along the product lifecycle?

What information system will be used for communication and information sharing throughout the supply chain to create awareness of the use of resources and raw materials?

What changes are needed in the production processes design to reduce the use of resources and raw materials?

What stock levels should be maintained in which locations taking into consideration resource scarcity and perishability? What transportation mode, routing and scheduling minimises the use of resources and raw materials?

What processes could be integrated among supply chain partners to reduce the use of resources and raw materials?
Blanke and Burdick (2005); Hagelaar and van der Vorst (2001); Herath et al. (2012); Jones (2002); Mancini et al. (2012); Nicholson et al. (2011); Page et al. (2012); Ridoutt and Pfister (2010); Van der Vorst et al. (2009) Henningsson et al. (2004)

Lehmann et al. (2011)

Davis and Sonesson (2008); Henningsson et al. (2004); Schliephake et al. (2009); Sonesson and Berlin (2003)

Cholette and Venkat (2009); Gebresenbet et al. (2011); Matopoulos and Bourlakis (2010); Vanek and Sun (2008) Hagelaar and van der Vorst (2001); Mena et al. (2011); Mintcheva (2005); Schliephake et al. (2009) 
Configuration decisions are structural in nature, and therefore, often they involve substantial expenditures. The first key configuration decision involves the definition of the member firms of the supply chain (Lambert and Cooper, 2000) and the member's physical facilities that will belong to the supply chain network (Hayes et al., 2005; Riopel et al., 2005). For example, some of the papers reviewed compared the environmental impact of fresh products supplied from different locations (Blanke and Burdick, 2005; Jones (2002), or investigated the possible trade-offs between increased localisation and supply chain costs (Nicholson et al., 2011). Furthermore, an integrated approach considering logistics, sustainability and food quality analysis for supply chain redesign has been proposed by Van Der Vorst et al. (2009).

The second configuration decision aims at considering alternative product design configurations to reduce the use of raw materials resources throughout the product lifecycle (Cigolini et al., 2004; Lambert and Cooper, 2000). For example, Henningsson et al. (2004) consider minimising the packaging of food products to decrease its subsequent environmental impact after consumption. Finally, the third configuration decision addresses the creation and maintenance of an effective system for communication and information sharing throughout the supply chain (Hayes et al., 2005; Riopel et al., 2005). Although the integration of information systems along supply chain members has been well-reported in the literature (Cigolini et al., 2004; Dehning et al., 2007), our review found only one article (Lehmann et al., 2011) dealing with the information system architecture for the information domain of the global warming potential, but not on tracking the raw material and resource use along the supply chain.

Tactical/operational decisions define the capacity of the chain and plan how the supply chain operates. The first decision in Table VI has the goal to continuously improve production processes (Cigolini et al., 2004; Lambert and Cooper, 2000) to reduce the use of resources along its various stages. This involves the implementation of improvement actions, such as, less consumer transport and packaging, reduction in energy consumption in industry and retail and reduction of waste (Davis and Sonesson, 2008). To support such decisions, researchers have analysed the environmental impacts of different future supply chains by developing models to simulate the various scenarios (Sonesson and Berlin, 2003). Although inventory management for perishable products has been studied in recent literature (Bakker et al., 2012; Blackburn and Scudder, 2009), we were not able to identify any in our review because our search keywords, such as "resource use" or "environmental", were not present in these papers. Still, the trade-off between resource scarcity and perishability seems to be unexplored till yet in the literature. Transportation network optimisation involves the decisions related to the transportation mode, routing and scheduling (Cigolini et al., 2004; Riopel et al., 2005) that minimise the use of resources and raw materials. By studying the environmental impact associated with each transportation link and storage echelon, researchers have proposed alternative transportation configurations (Cholette and Venkat, 2009).
In addition, the perishability of products in transportation decisions has been considered by Vanek and Sun (2008). Finally, supply chain coordination aims at exploring the potential of supply chain integration in reducing the use of raw materials and resources across the supply chain. For example, Mena et al. (2011) and Schliephake et al. (2009) showed that by exploring the supply chain members' interface, it is possible to identify the main root causes of waste in the supply chain and, consequently, improve waste management practices, eliminate process duplication and achieve greater resource efficiency across the supply chain. From this overview, we may conclude that tactical/operational decisions have not received much emphasis and that more research is needed into analysing the impacts and/or trade-offs of L\&SCM decisions in the use of resources and raw materials.

\section{Overview}

Table VII presents an overview of the classification of all reviewed papers with the number of articles on each coding area. From this table, it becomes clear what main issues are tackled in the research papers.

\section{Discussion}

This paper provided a systematic review of the literature on articles dealing with RESC in the agri-food sector. We will now first summarise and discuss the main findings and then propose a research agenda for RESC.

\section{Existing research}

The first research question in our research was to identify the key characteristics of RESC. An assessment of the literature showed two leading theories, namely, NRBV and RDT, which led us to four characteristics of RESC: resource aware, resource sparing, resource sensitive and resource responsive. Successively, we conducted a literature review to determine the current state-of-the-art and identify research opportunities for building RESC by food industry.

The analysis of the literature (Table VII) shows that not much emphasis has been placed on the use of specific resources. Similarly, although there have been articles looking at the entire food supply chain, the majority focuses on specific stages, mainly primary production and distribution and less on processing and storage/handling. Regarding the methods employed, LCA is by far the most frequently used method, and it can also be argued that the method has been rarely used in combination with other methods.

Overall, one can state that the type of resources that are analysed and the indicators used have been aligned to the existing methods, foremost LCA. With regard to the impact assessment and the indicators used, $\mathrm{CO}_{2}$ footprint dominates the research efforts. L\&SCM implications of resource use and scarcity have not received much attention in the literature so far as Table VII demonstrates.

Finally, in terms of the research approaches adopted, these seem to be primarily empirically driven (e.g. case study and models). Instead, survey-driven research that could be used to explain firm's supply chain decisions and behaviour was essentially missing. This explains also the lack of use of the theoretical lenses introduced in the first part. We argue that as the interest in both resource efficiency and in the impact of 
Table VII Overview of the classification of all reviewed papers

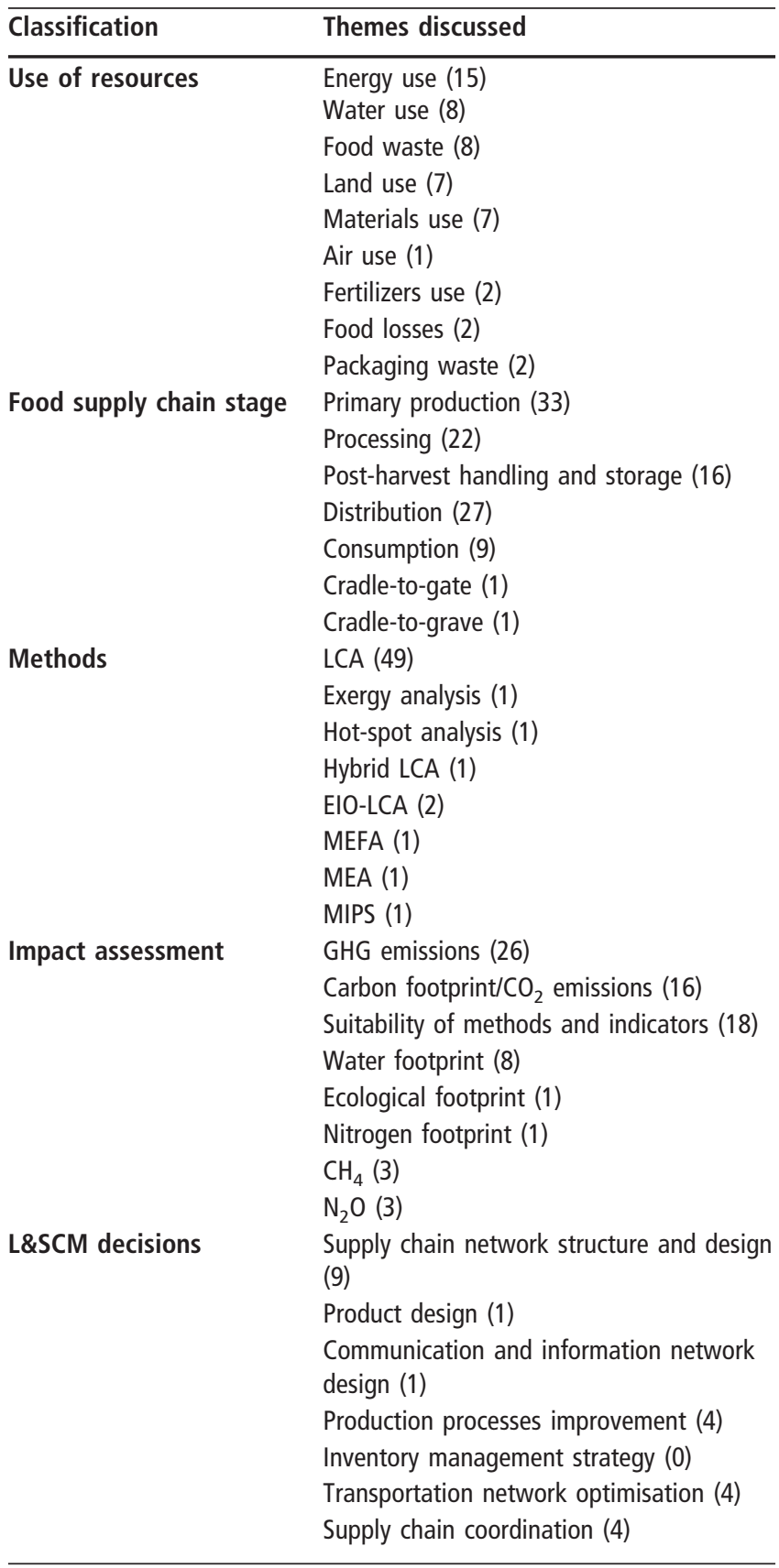

resource scarcity on supply chains grows, there will be an increased need to understand firm's practises and managers' decisions on resource efficiency. However, we acknowledge that because of the novelty of this research theme, there is still strong need for exploratory, rather than confirmatory research, so as to build a body of empirical evidence. The proposed RESC framework can function as a guide to practitioners and researchers to assess and further develop such practices and decisions.

\section{Future research directions and priorities}

From the literature review, it became clear that RESC - and its characteristics and main themes - are not yet fully studied and far from understood. More importantly, with the literature review and the proposed RESC framework, our understanding of how to build RESC so as to guide practitioners in its implementation and academics in their future research has been improved. The research has given insights into actors in food supply chains in those areas that need to be strengthened, and in Table VIII, we propose an agenda for future research.

\section{Multi-disciplinary methods for resource use and impact analyses}

Existing research has led to the development of many different methods to assess resource usage and impact. Research on these concepts becomes even more complex when done in the context of the agri-food supply chain because multidisciplinary approaches need to be adopted (e.g. agriculture and food production, packaging, sourcing and purchasing, logistics and transportation and food policy). Most of the existing approaches in the literature have taken a rather incomplete view, emphasising on either the use of resources and their environmental impact or the economic one. This is because existing methodologies (e.g. value stream mapping, value chain analysis [VCA], LCA) are used in isolation and not in a combinative way. What is more, existing methodologies treat supply chains as something static, failing to incorporate their complex and dynamic nature. Therefore, research in this field requires a combination of methods and techniques. Although LCA is considered to be an appropriate technique for assessing environmental impacts associated with all the stages of a product's lifecycle, there is a question of whether it can help in constructing more complex models and calculating more complex resource-based metrics. Despite the fact that there have been some efforts (Hagelaar and van der Vorst, 2001; Fearne and Norton, 2009; Paju et al., 2010) to combine the above-mentioned methodologies, this has been very sporadic and limited in terms of the data collected. For example, in one of the very few researches in the food chain by Soosay et al. (2012), a more integrated approach was attempted with LCA being combined with VCA. However, the emphasis given on the value created was purely from the consumer's perspective, hence, not on the efficient use of resources.

\section{Assessment methods for resource sensitivity and responsiveness}

More research is needed, both conceptual and empirical, on the implications of resource scarcity and changes at the strategic level of designing supply chains. In addition to the operational and tactical level of the above-mentioned classifications, there is also a need to explore whether or not and how L\&SCM decisions will affect the overall configuration of future food supply chains in an era of resource scarcity and depletion. We need to be able to understand the trade-offs of logistics/supply chain decisions in the use of multiple types of (scarce) resources. For example, in the design phase of an agri-food product, resource implications of the design decisions need to be investigated to examine and question sourcing practices and identifying alternative scenarios. British bread production, for example, the last 30 years moved from 80 per cent imported wheat in its supply 
Table VIII Main future research directions derived from the review

\begin{tabular}{ll}
\hline Research directions & Analyse and diagnose \\
\hline Internal RESC characteristic & $\begin{array}{l}\text { Resource aware: } \\
\text { Create insights about the use of resources in the supply chain } \\
\text { and the impact it has on performance and the environment }\end{array}$ \\
External RESC characteristic & $\begin{array}{l}\text { Resource sensitive: } \\
\text { Capture external changes in the availability of natural resources }\end{array}$
\end{tabular}

Main research opportunities

\section{Type of resources analysed:}

Include in the analyses multiple environmental resources (e. $g$. $\mathrm{CO}_{2}$, water, energy) next to raw materials and packaging

Take into account resource scarcity risks and associated implications at the company level

Impact assessment methods:

Gather consistent and transparent data on the impacts of the resource use in the food chain

Conduct empirical and comparative research that supports assessment method selection

Design integrated method incorporating strengths of multiple methods as well as chain dynamics

RESC indicators:

Define complete, integrated and chain-wide RESC indicators

Gather data that allows for the examination of the goodness of fit of the indicators

Food supply chain stage studied:

Put more emphasis on processing, post-harvest handling, storage and consumer

Conduct a truly broad cradle-to-grave analysis of the supply chain

\section{Act and improve}

Resource sparing:

Continuously improve operations and reduce the use of resources along the supply chain stages Resource responsive:

Develop strategies aimed at mitigating the effects of natural resource scarcity

L\&SCM decisions:

What types of relationships and partnerships do companies need to develop with their suppliers and customers so as to create more RESC? Create full insights into impacts and/or tradeoffs of L\&SCM decisions in the use of resources and raw materials

Design information system architecture for tracking the raw material and resource use along the supply chain Determine best improvement options for RESC network configuration; how resource scarcity and depletion affects overall configuration of food SCs?

Create insight in trade-off between resource scarcity and perishability in inventory and transport management decisions chain to 80 per cent domestically produced with just 20 per cent imported (Barling, 2007). What are the consequences, if any, of this shift with regard to resource efficiency in the bread supply chain? Similarly, when designing the distribution network, decisions related to the mode of transport and also to the nature of the distribution network (i.e. the number, location and design of distribution centres, the use of hub and spoke arrangements, the extent of cross-docking, etc.) need to be explored (Christopher, 2010). Although there has been recently an attempt to address some of these issues by Bell et al. (2012, 2013), it still remains more at a conceptual level, whereas there is no specific focus on agri-food supply chains.

\section{Implications for practitioners}

The findings and the conceptualisation of RESC in this study has managerial implications at different levels. At a tactical/ operational level, managers seeking to improve the resource efficiency in their supply chains should consider developing and implementing a set of resource use indicators that is based on continuous monitoring and analysis of critical resources, as well as develop flexible production systems and processes that reduce or eliminate waste but also ensure minimal use of scarce resources (e.g. energy, water, metals, minerals). At a strategic level, we argue that managers should have effective systems in place across their supply chain to identify and act on early-warning scarcity signs supplying real-time information and enabling fast implementation of preventive measures (e.g. inventory cushions and strategic stock piling and $\mathrm{R} \& \mathrm{D}$ on the substitution of resources at risk). Finally, we argue that much of the success in implementing the above will depend on supplier and customer involvement; therefore, we highlight the importance for managers to maintain a dialogue with suppliers/customers and consulting them so as to identify opportunities to improve resource efficiency of the complete supply chain.

\section{Conclusions}

This paper contributes to the body of SCM literature in the following ways: first, it proposes an RESC framework with four characteristics: resource aware, resource sparing, resource sensitive and resource responsive, using NRBV and RDT as theoretical foundations. This framework in novel because, to the best of our knowledge, no similar efforts have been made in the past to address the issue of resource efficiency in supply chains using also NRBV and RDT. As a consequence of the theoretical foundations used, we believe that this framework should be applicable to a number of different industries.

Our second contribution is related to the review of literature on RESC, specifically for agri-food industry on identified themes which revealed not only that the research coverage is limited to specific phases of the supply chain (e.g. in the food industry, the emphasis is on individual stages and at most from farm to fork, but not covering cradle to cradle) and that it takes a rather abstract view of the use of resources (e.g. overemphasising $\mathrm{GHG} / \mathrm{CO}_{2}$ emissions, limited collection of raw data and insufficient datasets on other resources) but also that the actual implications for supply chain processes, decisions and the overall chain performance are less considered.

Our research shows that resource efficiency is not the responsibility of one actor; it is the joint responsibility of all 
actors in the chain. This review has made clear that collaboration on the identification and sparing of potentially scarce materials will help improve chain robustness as well as the management of those scarce resources. The literature review resulted in important research opportunities and research questions that need to be addressed by both L\&SCM practitioners and scholars. We identified a need for innovative multi-disciplinary methods for resource use and impact analyses that can handle the dynamics and complexity of current (food) systems. Furthermore, there is a need for new assessment methods for resource sensitivity and responsiveness to determine the implications of resource scarcity and changes at the strategic level of designing supply chains. We need to be able to understand the trade-offs of foremost strategic logistics/supply chain decisions in the use of multiple types of (scarce) resources.

Further research should try and tackle issues such as: the impact of resource scarcity on the nature of supply chain relationships or the required supply chain partnerships, appropriate supply chain configurations to improve resource efficiency or the chain-wide indicators needed to measure resource efficiency. It is also clear that this research is not without limitations. Foremost, we reviewed the literature on RESC in a specific domain, namely, the agri-food industry, resulting in a sample size of 96 papers, which, although not small, it could be considered as such given the plethora of available papers on sustainable supply chains. Therefore, the body of literature from other domains could and should be studied to assess the generalisability of the findings of this research and further develop our insights into the new field of RESCs.

\section{Acknowledgements}

Aristides Matopoulos' research for this paper has been co-financed by the European Union (European Social Fund [ESF]) and Greek national funds through the Operational Program "Education and Lifelong Learning" of the National Strategic Reference Framework (NSRF) - Research Funding Program: Thales. Investing in knowledge society through the ESF.

Ana Barros' research for this paper was financed by the Project "NORTE-07-0124-FEDER-000057", financed by the North Portugal Regional Operational Programme (ON.2 O Novo Norte), under the NSRF, through the European Regional Development Fund, and by national funds, through the Portuguese funding agency, Fundação para a Ciência e a Tecnologia.

\section{References}

Abbasi, M. and Nilsson, F. (2012), "Themes and challenges in making supply chains environmentally sustainable", Supplv Chain Management: An International fournal, Vol. 17 No. 5, pp. 517-530.

Anderson, P. (1999), "Perspective: complexity theory and organization science", Organization Science, Vol. 10 No. 3, pp. 216-232.

Apaiah, R.K., Linnemann, A.R. and van der Kooi, H.J. (2006), "Exergy analysis: a tool to study the sustainability of food supply chains", Food Research International, Vol. 39 No. 1, pp. 1-11.

Ashby, A., Leat, M. and Hudson-Smith, M. (2012), "Making connections: a review of supply chain management and sustainability literature", Supplv Chain Management: An International fournal, Vol. 17 No. 5, pp. 497-516.

Ayers, R.U. (1989), "Industrial metabolism", Technology and Environment, pp. 23-49.

Bakker, M., Riezebos, J. and Teunter, R.H. (2012), "Review of inventory systems with deterioration as 2001", European fournal of Operational Research, Vol. 221 No. 2, pp. 275-284.

Barling, D. (2007), "Food supply chain governance and public health externalities: upstream policy interventions and the UK state", fournal of Agricultural E Environmental Ethics, Vol. 20 No. 2, pp. 285-300.

Barnett, H.J. and Morse, C. (1963), Scarcity and Growth: The Economics of Natural Resource Availability, John Hopkins University Press, Baltimore.

Barney, J. (1991), "Firm resources and sustained competitive advantage", fournal of Management, Vol. 17 No. 1, pp. 99-120.

Beekhuyzen, J. (2007), "Putting the pieces of the puzzle together: Using Nvivo for a literature review", Proceedings of QualIT2007: Qualitative Research, From the Margins to the Mainstream, Victoria University of Wellington, Wellington, 18-20 November.

Bell, J., Mollenkopf, D.A. and Stolze, H. (2013), "Natural resource scarcity and the closed-loop supply chain: a resource-advantage view", International fournal of Physical Distribution and Logistics Management, Vol. 43 No. 5, pp. 2-2.

Bell, J.E., Autry, C.W., Mollenkopf, D.A. and Thornton, L.M. (2012), "A natural resource scarcity typology: theoretical foundations and strategic implications for supply chain management", 7ournal of Business Logistics, Vol. 33 No. 2, pp. 158-166.

Binnemans, K., Pontikes, Y., Jones, P.T., Van Gerven, T. and Blanpain, B. (2013), "Recovery of rare earths from industrial waste residues: a concise reviewed", Proceedings of the 3rd International Slag Valorisation Symposium: the Transition to Sustainable Materials Management, pp. 191-205.

Blackburn, J. and Scudder, G. (2009), "Supply chain strategies for perishable products: the case of fresh produce", Production and Operations Management, Vol. 18 No. 2, pp. 129-137.

Blanke, M. and Burdick, B. (2005), "Food (miles) for thought-energy balance for locally-grown versus imported apple fruit (3 pp)", Environmental Science and Pollution Research, Vol. 12 No. 3, pp. 125-127.

Brown, S.L. and Eisenhardt, K.M. (1997), "The art of continuous change: linking complexity theory and time-paced evolution in relentlessly shifting organizations", Administrative Science Ouarterly, Vol. 42 No. 1, pp. 1-34.

Burgess, K., Singh, P.J. and Koroglu, R. (2006), "Supply chain management: a structured literature review and implications for future research", International fournal of Operations and Production Management, Vol. 26 No. 7, pp. 703-729. 
Canals, L.M., Chapagain, A., Orr, S., Chenoweth, J., Anton, A. and Clift, R. (2010), "Assessing freshwater use impacts in LCA, part 2: case study of broccoli production in the UK and Spain", The International fournal of Life Cvcle Assessment, Vol. 15 No. 6, pp. 598-607.

Cellura, M., Ardente, F. and Longo, S. (2012), "From the LCA of food products to the environmental assessment of protected crops districts: a case-study in the south of Italy", foumal of Environmental Management, Vol. 93 No. 1, pp. 194-208.

Chan, F.T. (2003), "Performance measurement in a supply chain". The International fournal of Advanced Manufacturing Technologv, Vol. 21 No. 7, pp. 534-548.

Chien, M.K. and Shih, L.H. (2007), "An empirical study of the implementation of green supply chain management practices in the electrical and electronic industry and their relation to organizational performances", International Fournal of Environmental Science and Technologv, Vol. 4 No. 3, pp. 383-394.

Choi, T.Y., Dooley, K.J. and Rungtusanatham, M. (2001), "Supply networks and complex adaptive systems: control versus emergence", Zournal of Operations Management, Vol. 19 No. 3, pp. 351-366.

Cholette, S. and Venkat, K. (2009), "The energy and carbon intensity of wine distribution: a study of logistical options for delivering wine to consumers", fournal of Cleaner Production, Vol. 17 No. 16, pp. 1401-1413.

Christopher, M. (2010), Logistics and Supply Chain Management, 4th ed., Prentice Hall, Upper Saddle River, NJ.

Cigolini, R., Cozzi, M. and Perona, M. (2004), "A new framework for supply chain management: conceptual model and empirical test", International fournal of Operations and Production Management, Vol. 24 No. 1, pp. 7-41.

Dalgaard, T., Olesen, J.E., Petersen, S.O., Petersen, B.M., Jørgensen, U., Kristensen, T., Hutchings, N.J., Gyldenkærne, S. and Hermansen, J.E. (2011), "Developments in greenhouse gas emissions and net energy use in Danish agriculture-How to achieve substantial $\mathrm{CO}_{2}$ reductions?", Environmental Pollution, Vol. 159 No. 11, pp. 3193-3203.

Davis, J. and Sonesson, U. (2008), "Life cycle assessment of integrated food chains - a Swedish case study of two chicken meals", The International fournal of Life Cvcle Assessment, Vol. 13 No. 7, pp. 574-584.

Dawson, C. and Hilton, J. (2011), "Fertiliser availability in a resource-limited world: production and recycling of nitrogen and phosphorus", Food Policy, Vol. 36 No. 1, pp. S14-S22.

Defee, C.C., Williams, B., Randall, W.S. and Thomas, R. (2010), "An inventory of theory in logistics and SCM research", International fournal of Logistics Management, Vol. 21 No. 3, pp. 404-489.

DEFRA (2012), "Sustainable business and resource efficiency", 16 March, available at: http:/webarchive. nationalarchives.gov.uk/20130123162956/http:/www. defra.gov.uk/environment/economy/business-efficiency/ (accessed at 12 September 2014).

Dehning, B., Richardson, V.J. and Zmud, R.W. (2007), "The financial performance effects of IT-based supply chain management systems in manufacturing firms", fournal of Operations Management, Vol. 25 No. 4, pp. 806-824.

Donaldson, L. (2001), The Contingency Theory of Organizations, Sage, Thousand Oaks, CA.

Drives and Control (2013), "Rare-earth crisis sparks quest for alternative motors", available at: www.drives.co.uk/ fullstory.asp?id=3040 (accessed 21 May 2013).

Ellram, L.M., Tate, W.L. and Feitzinger, E.G. (2013), "Factor-market rivalry and competition for supply chain resources", Zournal of Supply Chain Management, Vol. 49 No. 1, pp. 29-46.

European Commission (2011), "A resource-efficient Europe Flagship initiative under the Europe 2020 strategy", Communication from the Commission to the European Parliament, the Council, the European Economic and Social Committee and the Committee of the Regions, Brussels.

FAO (2011), Energy-Smart for People and Climate Issue Paper, Food and Agriculture Organization of the United Nations, Rome.

Fearne, A. and Norton, A. (2009), "Sustainable value stream mapping in the food industry", in Waldron, K. (Ed.), Handbook of Waste Management and Co-Product Recovery in Food Processing, Woodhead Publishing, Cambridge.

Fisher, M.L. (1997), "What is the right supply chain for your products?", Harvard Business Review, Vol. 75 No. 2, pp. 105-116.

FoodDrinkEurope (2012), "Environmental sustainability vision towards 2030", available at: www.fooddrinkeurope. eu/publication/fooddrinkeurope-launches-environmentalsustainability-vision-for-2030 (accessed 15 April 2012).

Ford (2013), "Sustainability Report 2012-2013", available at: http://corporate.ford.com/microsites/sustainability-report2012-13/supply-materials-elements (accessed 15 April 2013).

Frosch, R.A. and Gallopoulos, N.E. (1989), "Strategies for manufacturing", Scientific American, Vol. 261 No. 3, pp. 144-152.

Gebresenbet, G., Nordmark, I., Bosona, T. and Ljungberg, D. (2011), "Potential for optimised food deliveries in and around Uppsala city, Sweden", fournal of Transport Geographv, Vol. 19 No. 6, pp. 1456-1464.

Gerbens-Leenes, P., Moll, H. and Schoot Uiterkamp, A. (2003), "Design and development of a measuring method for environmental sustainability in food production systems", Ecological Economics, Vol. 46 No. 2, pp. 231-248.

Giljum, S., Behrens, A., Hinterberger, F., Lutz, C. and Meyer, B. (2008), "Modelling scenarios towards a sustainable use of natural resources in Europe", Environmental Science \& Policy, Vol. 11 No. 3, pp. 204-216.

Giljum, S., Burger, E., Hinterberger, F., Lutter, S. and Bruckner, M. (2011), “A comprehensive set of resource use indicators from the micro to the macro level", Resources, Conservation and Recvcling, Vol. 55 No. 3, pp. 300-308.

Glaser, B. and Strauss, A. (1967), The Discovery Grounded Theory: Strategies for Qualitative Inquiry, Aldine, Chicago, IL.

Grasso, V.B. (2011), "Rare Earth elements in national defense: background, oversight issues, and options for congress", DTIC Document. 
Gunasekaran, A. and Kobu, B. (2007), "Performance measures and metrics in logistics and supply chain management: a review of recent literature (1995-2004) for research and applications", International foumal of Production Research, Vol. 45 No. 12, pp. 2819-2840.

Gunasekaran, A., Lai, K.H. and Cheng, T.C.E. (2008), "Responsive supply chain: a competitive strategy in a networked economy", Omega, Vol. 36 No. 4, pp. 549-564.

Gustavsson, J., Cederberg, C., Sonesson, U., van Otterdijk, R. and Meybeck, A. (2011), Global Food Losses and Food Waste: Extent, Causes and Prevention, Food and Agriculture Organisation of the United Nations (FAO), Rome, p. 29.

Haberl, H., Fischer-Kowalski, M., Krausmann, F., Weisz, H. and Winiwarter, V. (2004), "Progress towards sustainability? What the conceptual framework of material and energy flow accounting (MEFA) can offer", Land Use Policy, Vol. 21 No. 3, pp. 199-213.

Hagelaar, G.J. and van der Vorst, J.G. (2001), "Environmental supply chain management: using life cycle assessment to structure supply chains", The International Food and Agribusiness Management Review, Vol. 4 No. 4, pp. 399-412.

Hague Centre for Strategic Studies (HCSS) (2012), "Risks and opportunities in the global phosphate rock market robust strategies in times of uncertainty, No. 17", available at: www.snb.nl/files/Nieuws/Internet/Rapport_Marjoleinde-Ridder_Fosfaat.pdf (accessed 21 May 2013).

Hart, S. (1995), "A natural-resource based view of the firm", Academv of Management Review, Vol. 20 No. 4, pp. 986-1014.

Hart, S.L. and Dowell, G. (2011), "Invited editorial: a natural-resource-based view of the firm fifteen years after", fournal of Management, Vol. 37 No. 5, pp. 1464-1479.

Hassini, E., Surti, C. and Searcy, C. (2012), "A literature review and a case study of sustainable supply chains with a focus on metrics", International fournal of Production Economics, Vol. 140 No. 1, pp. 69-82.

Hayes, R., Pisano, G., Upton, D. and Wheelwright, S. (2005), Operations, Strategy, and Technology: Pursuing the Competitive Edge, John Wiley \& Sons, New York, NY.

Hendrickson, C.T., Lave, L.B. and Matthews, H.S. (2006), Environmental Life Cycle Assessment of Goods and Services: An Input-Output Approach, Resources for the Future Press, Washington, DC.

Henningsson, S., Hyde, K., Smith, A. and Campbell, M. (2004), "The value of resource efficiency in the food industry: a waste minimisation project in East Anglia, UK", Fournal of Cleaner Production, Vol. 12 No. 5, pp. 505-512.

Herath, I., Green, S., Singh, R., Horne, D., van der Zijpp, S. and Clothier, B. (2012), "Water footprinting of agricultural products: a hydrological assessment for the water footprint of New Zealand's wines", fournal of Cleaner Production, Vol. 72 No. 1, pp. 110-119.

Hervani, A.A., Helms, M.M. and Sarkis, J. (2005), "Performance measurement for green supply chain management", Benchmarking: An International fournal, Vol. 12 No. 4, pp. 330-353.

Honda (2013), "News releases 2013”, available at: http:// world.honda.com/news/2013/c130303Reuse-Rare-EarthMetals (accessed 21 May 2013).
Institute for Sustainable Future, (IFS) (2010), "Securing a sustainable phosphorus future for Australia: implications of global phosphorus scarcity and possible solutions", in White, S., Cordell, D. and Moore, D. (Eds), available at: www.isf.uts.edu.au/publications/whitecordellmoore2010 phosphorusfuture.pdf (accessed 21 May 2013).

International Organization for Standardization (ISO) (2006a), "ISO 14040:2006(E) Environmental Manage-ment - Life Cycle Assessment - Principles and framework", Impact Assessment and Intensity Metrics, 107, ISO, Geneva.

International Organization for Standardization (ISO) (2006b), "ISO 14044:2006(E) Environmental Manage-ment - Life Cycle Assessment - Requirements and guidelines", ISO, Geneva.

Jeswani, H.K. and Azapagic, A. (2011), "Water footprint: methodologies and a case study for assessing the impacts of water use", fournal of Cleaner Production, Vol. 19 No. 12, pp. 1288-1299.

Jones, A. (2002), "An environmental assessment of food supply chains: a case study on dessert apples", Environmental Management, Vol. 30 No. 4, pp. 560-576.

Kantipuly, C.J. and Westland, A.D. (1988), "Review of methods for the determination of lanthanides in geological samples", Talanta, Vol. 35 No. 1, pp. 1-13.

Khan, S. and Hanjra, M.A. (2009), "Footprints of water and energy inputs in food production-Global perspectives", Food Policv, Vol. 34 No. 2, pp. 130-140.

Kist, L.T., Moutaqi, S.E. and Machado, E.L. (2009), "Cleaner production in the management of water use at a poultry slaughterhouse of Vale do Taquari, Brazil: a case study", foumal of Cleaner Production, Vol. 17 No. 13, pp. 1200-1205.

Krippendorff, K. (2004), Content Analysis: An Introduction to its Methodology, 2nd ed., Sage Publications, Newbury Park, CA.

Kummu, M., De Moel, H., Porkka, M., Siebert, S., Varis, O. and Ward, P. (2012), "Lost food, wasted resources: Global food supply chain losses and their impacts on freshwater, cropland, and fertiliser use", Science of the Total Environment, Vol. 438 No. 1, pp. 477-489.

Lambert, D.M. and Cooper, M.C. (2000), "Issues in supply chain management", Industrial Marketing Management, Vol. 29 No. 1, pp. 65-83.

Lawrence, P.R. and Lorsch, J.W. (1967), Organization and Environment, Harvard University Press, Cambridge, MA.

Leach, A.M., Galloway, J.N., Bleeker, A., Erisman, J.W., Kohn, R. and Kitzes, J. (2012), “A nitrogen footprint model to help consumers understand their role in nitrogen losses to the environment", Environmental Development, Vol. 1 No. 1, pp. 40-66.

Lehmann, R.J., Hermansen, J.E., Fritz, M., Brinkmann, D., Trienekens, J. and Schiefer, G. (2011), "Information services for European pork chains-closing gaps in information infrastructures", Computers and Electronics in Agriculture, Vol. 79 No. 2, pp. 125-136.

Leopold, L.B. (1971), A Procedure for Evaluating Environmental Impact, US Department of the Interior, Wasington, DC. 
Liedtke, C., Baedeker, C., Kolberg, S. and Lettenmeier, M. (2010), "Resource intensity in global food chains: the hot spot analysis", British Food Fournal, Vol. 112 No. 10, pp. 1138-1159.

Lynas (2012), "Lynas corporation 2012 annual report", available at: www.lynascorp.com/Annual\%20Reports/7437_ Lynas_AR12_ALL_v20_FA2_-_1158713.pdf (accessed 21 May 2013).

Mancini, L., Lettenmeier, M., Rohn, H. and Liedtke, C. (2012), "Application of the MIPS method for assessing the sustainability of production-consumption systems of food", Zournal of Economic Behavior E Organization, Vol. 81 No. 3, pp. 779-793.

Marc, A.R. (2008), Exergy: Analysis, Encyclopedia of Energy Engineering and Technology, Taylor \& Francis, Boca Raton, FL, pp. 645-654.

Matopoulos, A. and Bourlakis, M. (2010), "Sustainability practices and indicators in food retail logistics: findings from an exploratory study", fournal on Chain and Network Science, Vol. 10 No. 3, pp. 207-218.

Mattila, T., Helin, T. and Antikainen, R. (2012), "Land use indicators in life cycle assessment", The International fournal of Life Cucle Assessment, Vol. 17 No. 3, pp. 277-286.

Meisterling, K., Samaras, C. and Schweizer, V. (2009), "Decisions to reduce greenhouse gases from agriculture and product transport: LCA case study of organic and conventional wheat", fournal of Cleaner Production, Vol. 17 No. 2, pp. 222-230.

Mena, C., Adenso-Diaz, B. and Yurt, O. (2011), “The causes of food waste in the supplier-retailer interface: evidences from the UK and Spain", Resources, Conservation and Recvcling, Vol. 55 No. 6, pp. 648-658.

Mennenga, M., Thiede, S., Beier, J., Dettmer, T., Kara, S. and Herrmann, C. (2012), A Forecasting Model for the Evaluation of Future Resource Availability, Leveraging Technology for a Sustainable World, Springer, Heidelberg, pp. 449-454.

Miemczyk, J., Johnsenm, T.E. and Macquet, M. (2012), "Sustainable purchasing and supply management: a structured literature review of definitions and measures at the dyad, chain and network levels", Supply Chain Management: An International fournal, Vol. 17 No. 5, pp. 478-496.

Mintcheva, V. (2005), "Indicators for environmental policy integration in the food supply chain (the case of the tomato ketchup supply chain and the integrated product policy)", fournal of Cleaner Production, Vol. 13 No. 7, pp. 717-731.

Mundler, P. and Rumpus, L. (2012), "The energy efficiency of local food systems: a comparison between different modes of distribution", Food Policy, Vol. 37 No. 6, pp. 609-615.

Narasimhan, R. and Talluri, S. (2009), "Perspectives on risk management in supply chains", fournal of Operations Management, Vol. 27 No. 2, pp. 114-118.

Nicholson, C.F., Gómez, M.I. and Gao, O.H. (2011), "The costs of increased localization for a multiple-product food supply chain: dairy in the United States", Food Policv, Vol. 36 No. 2, pp. 300-310.

Nijdam, D., Rood, T. and Westhoek, H. (2012), “The price of protein: Review of land use and carbon footprints from life cycle assessments of animal food products and their substitutes", Food Policy, Vol. 37 No. 6, pp. 760-770.

Page, G., Ridoutt, B. and Bell, B. (2012), "Carbon and water footprint tradeoffs in fresh tomato production", fournal of Cleaner Production, Vol. 32 No. 1, pp. 219-226.

otti, B. (2012), "Carbon and water footprint tradeoffs in fresh tomato production", fournal of Cleaner Production, Vol. 32 No. 1, pp. 219-226.

Paju, M., Heilala, J., Hentual, M., Heikkila, A., Johansson, B., Leong, S. and Lyons, S. (2010), "Framework and indicators for a sustainable manufacturing mapping methodology", Proceedings of the 2010 Winter Simulations Conference, Baltimore, MD, 5-8 December, pp. 3411-3422.

Paulraj, A. and Chen, I.J. (2007), "Environmental uncertainty and strategic supply management: a resource dependence perspective and performance implications", foumal of Supplv Chain Management, Vol. 43 No. 3, pp. 29-42.

Pfeffer, J. and Salancik, G.R. (1978), The External Control of Organizations: A Resource Dependence Perspective, Harper and Row Sterns, New York, NY.

Phosagro (2011), "The phosphate industry, 2011 Annual report”, available at: http://ar2011.phosagro.com/eng/ business_review/phosphate_industry, (accessed 21 May 2013).

Plassmann, K., Norton, A., Attarzadeh, N., Jensen, M., Brenton, P. and Edwards-Jones, G. (2010), "Methodological complexities of product carbon footprinting: a sensitivity analysis of key variables in a developing country context", Environmental Science \& Policy, Vol. 13 No. 5, pp. 393-404.

Ponsioen, T. and Blonk, T. (2012), "Calculating land use change in carbon footprints of agricultural products as an impact of current land use", fournal of Cleaner Production, Vol. 28 No. 1, pp. 120-126.

PwC (2011), "Minerals and metals scarcity in manufacturing: the ticking time bomb", Sustainable Materials Management Report, available at: www.pwc.com/en_GX/gx/ sustainability/research-insights/assets/impact-of-mineralsmetals-scarcity-on-business.pdf (accessed 25 March 2013).

Reichhart, A. and Holweg, M. (2007), "Creating the customer-responsive supply chain: a reconciliation of concepts", International fournal of Operations \& Production Management, Vol. 27 No. 11, pp. 1144-1172.

Ridoutt, B.G. and Pfister, S. (2010), “A revised approach to water footprinting to make transparent the impacts of consumption and production on global freshwater scarcity", Global Environmental Change, Vol. 20 No. 1, pp. 113-120.

Ridoutt, B., Juliano, P., Sanguansri, P. and Sellahewa, J. (2010), "The water footprint of food waste: case study of fresh mango in Australia", fournal of Cleaner Production, Vol. 18 No. 16, pp. 1714-1721.

Riopel, R., Langevin, A. and Campbell, J.F. (2005), "The network of logistics decisions", in Langevin, A. and Riopel, R. (Eds), Logistics Systems: Design and Optimization, Springer, Heidelberg, pp. 1-38.

Ritthoff, M., Rohn, H., Liedtke, C. and Merten, T. (2002), "Calculating MIPS - resource productivity of products and services”, Wuppertal Special 27e, Wuppertal Institute, available at: www.mips-online.info, (accessed 25 March 2013). 
Rousseau, D.M., Manning, J. and Denyer, D. (2008), “11 evidence in management and organizational science: assembling the field's full weight of scientific knowledge through syntheses", The Academv of Management Annals, Vol. 2 No. 1, pp. 475-515.

Sanyé, E., Oliver-Solà, J., Gasol, C.M., Farreny, R., Rieradevall, J. and Gabarrell, X. (2012), "Life cycle assessment of energy flow and packaging use in food purchasing", fournal of Cleaner Production, Vol. 25 No. 1, pp. 51-59.

Sarkis, J., Zhu, Q. and Lai, K.H. (2011), “An organizational theoretic review of green supply chain management literature", International fournal of Production Economics, Vol. 130 No. 1, pp. 1-15.

Schliephake, K., Stevens, G. and Clay, S. (2009), "Making resources work more efficiently-the importance of supply chain partnerships", fournal of Cleaner Production, Vol. 17 No. 14, pp. 1257-1263.

SCU (2012), "Science for environment policy in-depth report: resource efficiency indicators report produced for the European Commission DG Environment, Science Communication Unit", University of the West of England, Bristol, available at: http://ec.europa.eu/scienceenvironment-policy, (accessed 25 March 2013).

Seuring, S. and Müller, M. (2008), "From a literature review to a conceptual framework for sustainable supply chain management", Fournal of Cleaner Production, Vol. 16 No. 15, pp. 1699-1710.

Skilton, P.F. (2011), "Getting the reader to 'I get it!': clarification, differentiation and illustration", fournal of Supply Chain Management, Vol. 47 No. 2, pp. 22-28.

Sonesson, U. and Berlin, J. (2003), "Environmental impact of future milk supply chains in Sweden: a scenario study", fournal of Cleaner Production, Vol. 11 No. 3, pp. 253-266.

Soosay, C., Fearne, A. and Dent, B. (2012), "Sustainable value chain analysis-a case study of Oxford Landing from 'vine to dine"', Supplv Chain Management: An International fournal, Vol. 17 No. 1, pp. 68-77.

Suh, S., Lenzen, M., Treloar, G.J., Hondo, H., Horvath, A., Huppes, G., Jolliet, O., Klann, U., Krewitt, W. and Moriguchi, Y. (2004), "System boundary selection in life-cycle inventories using hybrid approaches", Environmental Science \& Technologv, Vol. 38 No. 3, pp. 657-664.

Tranfield, D., Denyer, D. and Smart, P. (2003), "Towards a methodology for developing evidence-informed management knowledge by means of systematic review", British fournal of Management, Vol. 14 No. 3, pp. 207-222.

Unilever (2012), "Unilever sustainable living: sustainable sourcing online report 2012”, available at: http://unilever. com/images/PDF_generator_-_Sustainable_sourcing_tcm 13-365054.pdf (accessed 25 September 2014).

United Nations Environment Programme (2012), “Global outlook on sustainable consumption and production policies: taking action together, 2012", Nairobi: UNEP, available at: www.unep.fr/shared/publications/pdf/DTIx149 8xPAGlobalOutlookonSCPPolicies.pdf (accessed 25 March 2013).

van Der Vorst, J.G., Tromp, S.O. and Zee, D.J.V.D. (2009), "Simulation modelling for food supply chain redesign; integrated decision making on product quality, sustainability and logistics", International fournal of Production Research, Vol. 47 No. 23, pp. 6611-6631.

Vanek, F. and Sun, Y. (2008), "Transportation versus perishability in life cycle energy consumption: a case study of the temperature-controlled food product supply chain", Transportation Research Part D: Transport and Environment, Vol. 13 No. 6, pp. 383-391.

Virtanen, Y., Kurppa, S., Saarinen, M., Katajajuuri, J.M., Usva, K., Mäenpää, I., Mäkelä, J., Grönroos, J. and Nissinen, A. (2011), "Carbon footprint of food-approaches from national input-output statistics and a LCA of a food portion", Fournal of Cleaner Production, Vol. 19 No. 16, pp. 1849-1856.

Vlajic, J.V., Vorst, J.G.A.J. and van der and Haijema, R. (2012), "A framework for designing robust food supply chains", International foumal of Production Economics, Vol. 137 No. 1, pp. 176-189.

Walker, H. and Jones, N. (2012), "Sustainable supply chain management across the UK private sector", Supplv Chain Management, Vol. 17 No. 1, pp. 15-28.

Wognum, P.M., Bremmers, H., Trienekens, J.H., van der Vorst, J.G.A.J. and Bloemhof, J.M. (2011), "Systems for sustainability and transparency of food supply chains - Current status and challenges", Advanced Engineering Informatics, Vol. 25 No. 1, pp. 65-76.

WTO (2009), "International trade statistics", available at: www.wto.org/english/res_e/statis_e/its2009_e/its09_toc_e. htm (accessed 20 January 2012).

Zhou, H. and Benton, W. Jr (2007), "Supply chain practice and information sharing", fournal of Operations Management, Vol. 25 No. 6, pp. 1348-1365.

Zonderland-Thomassen, M. and Ledgard, S. (2012), "Water footprinting-a comparison of methods using New Zealand dairy farming as a case study", Agricultural Sustems, Vol. 110 No. 1, pp. 30-40.

\section{Further reading}

Adebanjo, D., Mahoney, F. and Kehoe, D. (2008), "Reducing food miles-analysis of the perceptions of stakeholders in Northwest England", Supply Chain Forum: an International fournal, Vol. 9 No. 1, pp. 58-68.

Andersson, K., Eide, M.H., Lundqvist, U. and Mattsson, B. (1998), "The feasibility of including sustainability in LCA for product development", fournal of Cleaner Production, Vol. 6 No. 3, pp. 289-298.

Bazilian, M., Rogner, H., Howells, M., Hermann, S., Arent, D., Gielen, D., Steduto, P., Mueller, A., Komor, P. and Tol, R.S. (2011), "Considering the energy, water and food nexus: towards an integrated modelling approach", Energy Policy, Vol. 39 No. 12, pp. 7896-7906.

Beauchemin, K.A., Henry Janzen, H., Little, S.M., McAllister, T.A. and McGinn, S.M. (2010), "Life cycle assessment of greenhouse gas emissions from beef production in western Canada: a case study", Agricultural Sustems, Vol. 103 No. 6, pp. 371-379.

Bonesmo, H., Skjelvåg, A.O., Henry Janzen, H., Klakegg, O. and Tveito, O.E. (2012), "Greenhouse gas emission intensities and economic efficiency in crop production: a 
systems analysis of 95 farms", Agricultural Systems, Vol. 110 No. 1, pp. 142-151.

Bremmers, H., Trienekens, J.H., van der Vorst, J.G. and Bloemhof, J.M. (2011), "Systems for sustainability and transparency of food supply chains-Current status and challenges", Advanced Engineering Informatics, Vol. 25 No. 1, pp. 65-76.

Christopher, M., Mena, C., Khan, O. and Yurt, O. (2001), "Approaches to managing global sourcing risk", Supplv Chain Management: An International foumal, Vol. 16 No. 2, pp. 67-81.

Coley, D., Howard, M. and Winter, M. (2009), "Local food, food miles and carbon emissions: a comparison of farm shop and mass distribution approaches", Food Policv, Vol. 34 No. 2, pp. 150-155.

Cooper, J., Butler, G. and Leifert, C. (2011), "Life cycle analysis of greenhouse gas emissions from organic and conventional food production systems, with and without bio-energy options", NFAS-Wageningen fournal of Life Sciences, Vol. 58 No. 3, pp. 185-192.

Crosson, P., Shalloo, L., O’Brien, D., Lanigan, G., Foley, P., Boland, T. and Kenny, D. (2011), "A review of whole farm systems models of greenhouse gas emissions from beef and dairy cattle production systems", Animal Feed Science and Technologv, Vol. 166 No. 1, pp. 29-45.

Dorward, L.J. (2012), "Where are the best opportunities for reducing greenhouse gas emissions in the food system (including the food chain)? A comment", Food Policy, Vol. 37 No. 4, pp. 463-466.

Edwards-Jones, G., Milà i Canals, L., Hounsome, N., Truninger, M., Koerber, G., Hounsome, B., Cross, P., York, E.H., Hospido, A. and Plassmann, K. (2008), "Testing the assertion that 'local food is best': the challenges of an evidence-based approach", Trends in Food Science E Technology, Vol. 19 No. 5, pp. 265-274.

Ferng, J.J. (2011), "Measuring and locating footprints: a case study of Taiwan's rice and wheat consumption footprint", Ecological Economics, Vol. 71 No. 1, pp. 191-201.

Flysjö, A., Henriksson, M., Cederberg, C., Ledgard, S. and Englund, J.E. (2011), "The impact of various parameters on the carbon footprint of milk production in New Zealand and Sweden", Agricultural Sustems, Vol. 104 No. 6, pp. 459-469.

Flysjö, A., Cederberg, C., Henriksson, M. and Ledgard, S. (2012), "The interaction between milk and beef production and emissions from land use change-critical considerations in life cycle assessment and carbon footprint studies of milk", fournal of Cleaner Production, Vol. 28 No. 1, pp. 134-142.

Franks, J.R. and Hadingham, B. (2012), "Reducing greenhouse gas emissions from agriculture: avoiding trivial solutions to a global problem", Land Use Policy, Vol. 29 No. 4, pp. 727-736.

Fresco, L.O. (2009), "Challenges for food system adaptation today and tomorrow", Environmental Science \& Policv, Vol. 12 No. 4, pp. 378-385.

Garnett, T. (2011), "Where are the best opportunities for reducing greenhouse gas emissions in the food system (including the food chain)?", Food Policy, Vol. 36 No. 1, pp. S23-S32.
Gavronski, I., Klassen, R.D., Vachon, S. and Nascimento, L.F.M.D. (2011), "A resource-based view of green supply management", Transportation Research Part E: Logistics and Transportation Review, Vol. 47 No. 6, pp. 872-885.

Gunady, M.G., Biswas, W., Solah, V.A. and James, A.P. (2012), "Evaluating the global warming potential of the fresh produce supply chain for strawberries, romaine/cos lettuces (Lactuca sativa), and button mushrooms (Agaricus bisporus) in Western Australia using life cycle assessment (LCA)", 7ournal of Cleaner Production, Vol. 28 No. 1, pp. 81-87.

Hagemann, M., Hemme, T., Ndambi, A., Alqaisi, O. and Sultana, M.N. (2011), "Benchmarking of greenhouse gas emissions of bovine milk production systems for 38 countries", Animal Feed Science and Technologv, Vol. 166 No. 1, pp. 46-58.

Hagigi, M. and Sivakumar, K. (2009), "Managing diverse risks: An integrative framework", fournal of International Management, Vol. 15 No. 3, pp. 286-295.

Hall, G.M. and Howe, J. (2012), "Energy from waste and the food processing industry", Process Safety and Environmental Protection, Vol. 90 No. 3, pp. 203-212.

Hult, G.T.M., Ketchen, D.J. and Slater, S.F. (2004), "Information processing, knowledge development, and strategic supply chain performance", Academv of Management fournal, Vol. 47 No. 2, pp. 241-253.

Ilbery, B. and Maye, D. (2005), "Food supply chains and sustainability: evidence from specialist food producers in the Scottish/English borders", Land Use Policy, Vol. 22 No. 4, pp. 331-344.

Jefferies, D., Muñoz, I., Hodges, J., King, V.J., Aldaya, M., Ercin, A.E., Milà i Canals, L. and Hoekstra, A.Y. (2012), "Water footprint and life cycle assessment as approaches to assess potential impacts of products on water consumption: key learning points from pilot studies on tea and margarine", fournal of Cleaner Production, Vol. 33 No. 13, pp. 155-166.

Kendall, A., Yuan, J. and Brodt, S.B. (2013), "Carbon footprint and air emissions inventories for US honey production: case studies", The International fournal of Life Cycle Assessment, Vol. 18 No. 2, pp. 392-400.

Kim, M.H. and Kim, J.W. (2010), "Comparison through a LCA evaluation analysis of food waste disposal options from the perspective of global warming and resource recovery", Science of the Total Environment, Vol. 408 No. 19, pp. 3998-4006.

Kissinger, M. (2012), "International trade related food milesThe case of Canada", Food Policy, Vol. 37 No. 2, pp. 171-178.

Kristensen, T., Mogensen, L., Knudsen, M.T. and Hermansen, J.E. (2011), "Effect of production system and farming strategy on greenhouse gas emissions from commercial dairy farms in a life cycle approach", Livestock Science, Vol. 140 No. 1, pp. 136-148.

Neset, T.S.S. and Cordell, D. (2012), "Global phosphorus scarcity: identifying synergies for a sustainable future", Zournal of the Science of Food and Agriculture, Vol. 92 No. 1, pp. 2-6. 
Neto, B., Dias, A.C. and Machado, M. (2013), "Life cycle assessment of the supply chain of a Portuguese wine: from viticulture to distribution", The International fournal of Life Cvcle Assessment, Vol. 18 No. 3, pp. 590-602.

O’Brien, D., Shalloo, L., Patton, J., Buckley, F., Grainger, C. and Wallace, M. (2012), "A life cycle assessment of seasonal grass-based and confinement dairy farms", Agricultural Sustems, Vol. 107 No. 1, pp. 33-46.

Olesen, J.E., Schelde, K., Weiske, A., Weisbjerg, M.R., Asman, W.A. and Djurhuus, J. (2006), "Modelling greenhouse gas emissions from European conventional and organic dairy farms", Agriculture, Ecosystems E⿱ Environment, Vol. 112 No. 2, pp. 207-220.

Parfitt, J., Barthel, M. and Macnaughton, S. (2010), "Food waste within food supply chains: quantification and potential for change to 2050", Philosophical Transactions of the Roval Societv B: Biological Sciences, Vol. 365 No. 1554, pp. 3065-3081.

Pathak, H., Jain, N., Bhatia, A., Patel, J. and Aggarwal, P. (2010), "Carbon footprints of Indian food items", Agriculture, Ecosystems \& Environment, Vol. 139 No. 1, pp. 66-73.

Pelletier, N.L., Ayer, N.W., Tyedmers, P.H., Kruse, S.A., Flysjo, A., Robillard, G., Ziegler, F., Scholz, A.J. and Sonesson, U. (2007), "Impact categories for life cycle assessment research of seafood production systems: review and prospectus", The International foumal of Life Cucle Assessment, Vol. 12 No. 6, pp. 414-421.

Penker, M. (2006), "Mapping and measuring the ecological embeddedness of food supply chains", Geoforum, Vol. 37 No. 3, pp. 368-379.

Pretty, J.N., Ball, A.S., Lang, T. and Morison, J.I. (2005), "Farm costs and food miles: an assessment of the full cost of the UK weekly food basket", Food Policv, Vol. 30 No. 1, pp. 1-19.

Rizet, C., Browne, M., Cornelis, E. and Leonardi, J. (2012), "Assessing carbon footprint and energy efficiency in competing supply chains: review-case studies and benchmarking", Transportation Research Part D: Transport and Environment, Vol. 17 No. 4, pp. 293-300.

Rotz, C., Montes, F. and Chianese, D. (2010), "The carbon footprint of dairy production systems through partial life cycle assessment", Fournal of Dairv Science, Vol. 93 No. 3, pp. 1266-1282.

Roy, P., Nei, D., Orikasa, T., Xu, Q., Okadome, H., Nakamura, N. and Shiina, T. (2009), "A review of life cycle assessment (LCA) on some food products", fournal of Food Engineering, Vol. 90 No. 1, pp. 1-10.

Ruviaro, C.F., Gianezini, M., Brandão, F.S., Winck, C.A. and Dewes, H. (2012), "Life cycle assessment in Brazilian agriculture facing worldwide trends", fournal of Cleaner Production, Vol. 28 No. 1, pp. 9-24.

Salomone, R. and Ioppolo, G. (2012), "Environmental impacts of olive oil production: a life cycle assessment case study in the province of Messina (Sicily)", fournal of Cleaner Production, Vol. 28 No. 1, pp. 88-100.

Sarkis, J., Gonzalez-Torre, P. and Adenso-Diaz, B. (2010), "Stakeholder pressure and the adoption of environmental practices: the mediating effect of training", fournal of Operations Management, Vol. 28 No. 2, pp. 163-176.
Saunders, C. and Barber, A. (2008), "Carbon footprints, life cycle analysis, food miles: global trade trends and market issues", Political Science, Vol. 60 No. 1, pp. 73-88.

Schäfer, F. and Blanke, M. (2012), "Farming and marketing system affects carbon and water footprint-a case study using Hokaido pumpkin", Fournal of Cleaner Production, Vol. 28 No. 1, pp. 113-119.

Seuring, S. (2013), "A review of modeling approaches for sustainable supply chain management", Decision Support Sustems, Vol. 54 No. 4, pp. 1513-1520.

Shang, K.C., Lu, C.S. and Li, S. (2010), "A taxonomy of green supply chain management capability among electronics-related manufacturing firms in Taiwan", fournal of Environmental Management, Vol. 91 No. 5, pp. 1218-1226.

Shukla, M. and Jharkharia, S. (2013), "Agri-fresh produce supply chain management: a state-of-the-art literature review", International fournal of Operations \& Production Management, Vol. 33 No. 2, pp. 114-158.

Simpson, D. (2012), "Institutional pressure and waste reduction: the role of investments in waste reduction resources", International fournal of Production Economics, Vol. 139 No. 1, pp. 330-339.

Spiertz, H. (2012), "Avenues to meet food security: the role of agronomy on solving complexity in food production and resource use", European foumal of Agronomy, Vol. 43 No. 1, pp. 1-8.

Spiertz, J. and Ewert, F. (2009), "Crop production and resource use to meet the growing demand for food, feed and fuel: opportunities and constraints", NFAS-Wageningen Zournal of Life Sciences, Vol. 56 No. 4, pp. 281-300.

Styles, D., Schoenberger, H. and Galvez-Martos, J.L. (2012), "Environmental improvement of product supply chains: a review of European retailers' performance", Resources, Conservation and Recvcling, Vol. 65 No. 1, pp. 57-78.

Van Passel, S. (2013), "Food miles to assess sustainability: a revision", Sustainable Development, Vol. 21, pp. 1-17, DOI: $10.1002 / \mathrm{sd} .485$.

Vasileiou, K. and Morris, J. (2006), "The sustainability of the supply chain for fresh potatoes in Britain", Supplv Chain Management: An International foumal, Vol. 11 No. 4, pp. 317-327.

Vázquez-Rowe, I., Iribarren, D., Moreira, M.T. and Feijoo, G. (2010), "Combined application of life cycle assessment and data envelopment analysis as a methodological approach for the assessment of fisheries", The International Fournal of Life Cvcle Assessment, Vol. 15 No. 3, pp. 272-283.

Weber, C.L. and Matthews, H.S. (2008), "Food-miles and the relative climate impacts of food choices in the United States", Environmental Science \& Technologv, Vol. 42 No. 10, pp. 3508-3513.

Weiske, A., Vabitsch, A., Olesen, J.E., Schelde, K., Michel, J., Friedrich, R. and Kaltschmitt, M. (2006), "Mitigation of greenhouse gas emissions in European conventional and organic dairy farming", Agriculture, Ecosvstems \& Environment, Vol. 112 No. 2, pp. 221-232.

Yakovleva, N. (2007), "Measuring the sustainability of the food supply chain: a case study of the UK", Fournal of Environmental Policv E Planning, Vol. 9 No. 1, pp. 75-100. 
Yakovleva, N., Sarkis, J. and Sloan, T. (2012), "Sustainable benchmarking of supply chains: the case of the food industry", International foumal of Production Research, Vol. 50 No. 5, pp. 1297-1317.

Yuttitham, M., Gheewala, S.H. and Chidthaisong, A. (2011), "Carbon footprint of sugar produced from sugarcane in eastern Thailand", Zournal of Cleaner Production, Vol. 19 No. 17 , pp. $2119-2127$.

\section{About the authors}

Aristides Matopoulos is a Lecturer in Supply Chain and Logistics Management in the Engineering Systems and Management Group at Aston University. Aristides obtained a $\mathrm{PhD}$ in Supply Chain Management and E-business from the University of Macedonia in Greece, an MSc in Food Industry Management and Marketing from Imperial College, UK, and a BSc in Agricultural Studies from the Aristotle University of Thessaloniki. His research interests include sustainable supply chain management, environmental impact assessment of logistics operations particularly in the agri-food supply chain, while he has also done research in the design of humanitarian supply chains. His work has appeared in Supply Chain Management/Logistics outlets. $\mathrm{He}$ also acts as a reviewer in international journals in the above-mentioned fields. Aristides Matopoulos is the corresponding author and can be contacted at: a.matopoulos@aston.ac.uk

Ana Cristina Barros is a Senior Researcher at INESC TEC - INESC Technology and Science. She obtained a PhD in Engineering and Management from the Instituto Superior Técnico at the Universidade Técnica de Lisboa, Portugal, an MBA in logistics and entrepreneurship from the Technische Universität München, Germany, and an $\mathrm{MS}$ and BS in Chemical Engineering from the Universidade do Porto,
Portugal. Her research focuses on supply chain management, innovation networks and technology implementation management. She participated in the CMU-Portugal Faculty Exchange Program in the Department of Engineering and Public Policy at Carnegie Mellon University (2012), was Research Affiliate at the Center for Transportation and Logistics at the Massachusetts Institute of Technology, Cambridge, USA (2008-2011), and served as a Visiting Fellow of the Center for the Environment at Cornell University, New York State (2002). Ana Barros has been publishing and serving as a reviewer in peer reviewed journals. She teaches operations management-related disciplines in Masters and Executive Programmes and supervises Master and $\mathrm{PhD}$ students. She has several years of work experience in the procurement and production planning departments of German and Portuguese companies.

J.G.A.J. (Jack) van der Vorst (1970) is a Full Professor of Logistics and Operations Research and Head of the Logistics, Decision and Information Sciences Group at Wageningen University in the Netherlands. He obtained his PhD in 2000 with a thesis entitled "Effective Food Supply Chains; generating, modelling and evaluating supply chain scenarios" from Wageningen University. His current research focuses on the development of innovative logistics concepts in agri-food supply chain networks and related decision support models and tools, with emphasis on the themes Quality Controlled Logistics and Sustainable Agro-Food Logistics. Jack (co)authored many articles in peer-reviewed journals for which he also acts as a reviewer. $\mathrm{He}$ is a coordinator and/or work package leader in several EU projects and national co-innovation projects, and is a member of multiple (inter)national advisory boards.

For instructions on how to order reprints of this article, please visit our website: www.emeraldgrouppublishing.com/licensing/reprints.htm Or contact us for further details: permissions@emeraldinsight.com 